\title{
Reflective of the physician's eye
}

\author{
Five Centuries of European Prints from \\ the Collection of Drs. Jonathan \\ Meakins and Jacqueline McClaran: The \\ Physician's Eye \\ Montreal Museum of Fine Arts \\ Until Aug. 21, 2011.
}

$\mathrm{W}$ hen 17 th-century Spanish artist Jusepe de Ribera decided to create an image of Silenus, the Greek god of drunkenness, he wisely found a live model bearing the signs of what we now know to be alcohol-fueled cirrhosis of the liver. The model has a bloated belly. His breasts are as large a woman's. He has little body hair. And, in the resulting etching known as The Drunken Silenus, the intoxicated-looking model reclines in front of a grape press demanding to have his wine goblet refilled.

This 1628 print by Ribera is considered one of his best. One such print is owned by Dr. Jonathan Meakins, the former surgeon-in-chief of the McGill University Health Centre in Montréal, Quebec, and his wife, Dr. Jacqueline McClaran, a palliative care specialist at the Montreal General Hospital.

The Ribera is one of more than 200 European prints owned by the couple. About a third of the collection comprises this splendidly eclectic exhibition, which is dominated by 16th and 17 th-century prints from the Dutch

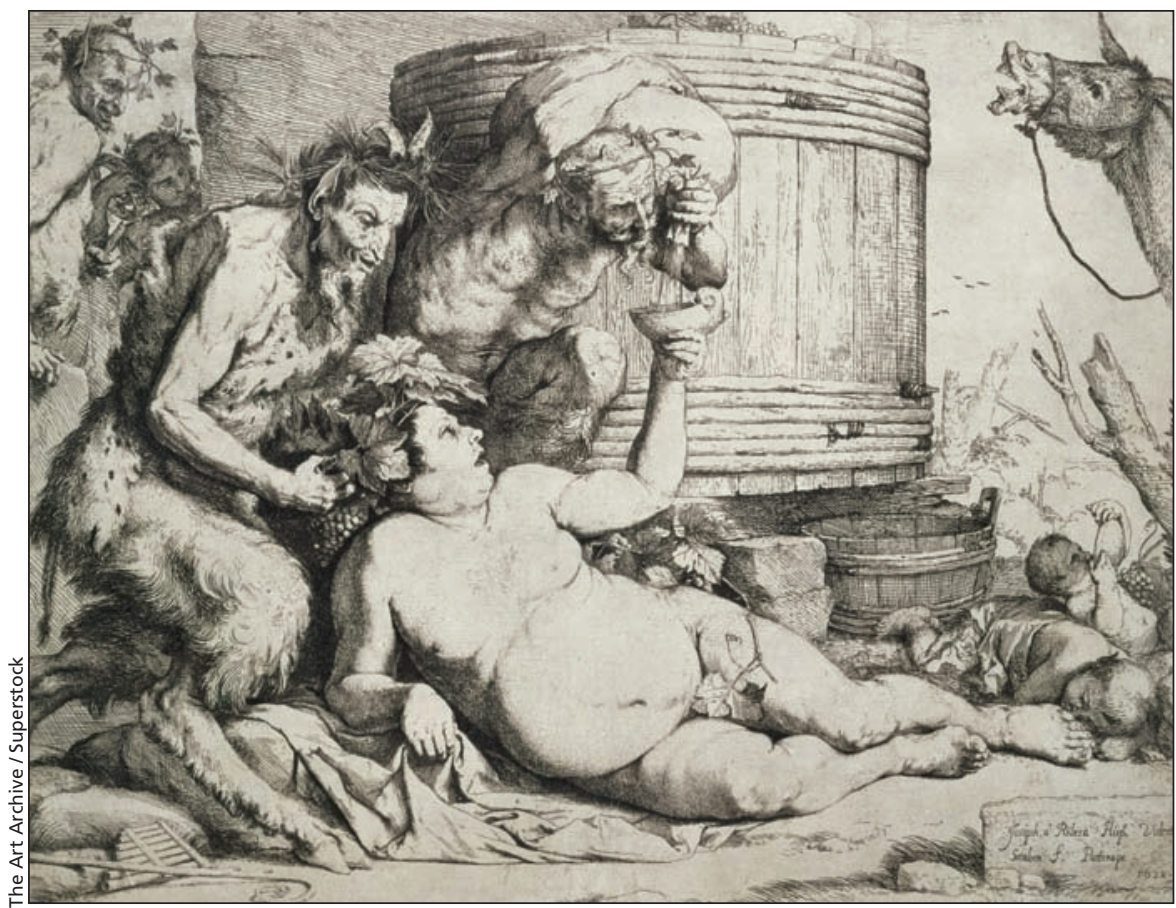

Jusepe de Ribera's The Drunken Silenus (1628), is one of the etchings Dr. Jonathan Meakins used in class to challenge his medical students to diagnose the illness of the model. (This particular version of the print is not from the exhibit.)

and half a dozen medically themed prints, including renditions of what the museum's associate chief curator, Hilliard Goldfarb, calls "quackery:" Dutch artist Lucas Van Leyden's The Surgeon, 1524, in which a man's head is sliced open to cure him of stupidity and two 1695 prints by Cornelis Dusart, The Heelmaster or The Country Surgeon, in which a barber drains a painful boil, and

\section{This splendidly eclectic exhibition is dominated by the Dutch Golden Age.}

Golden Age. There are also works by such Old Masters as Rembrandt and Durer, and even a few more contemporary works, such as Picasso's 1958 Portrait of Jacqueline, Right Profile.

The exhibition includes landscapes, Biblical scenes, depictions of village life
The Cupster (The Leech Woman), in which hot cups are applied to a leg to cure some infirmity. These scenes are comical, the patients look gullible and the "physicians" overflow with mischief and avarice. One can almost hear the jingling of ill-gotten coins.
The paucity of medically themed prints in the show reflects the fact only about five per cent of the doctors' collection has an obvious medical link. When they started collecting in 1983, they had no particular theme or focus; they simply purchased works that appealed to them. Later, as the collection grew, the doctors became more sophisticated collectors and felt the need to plug certain gaps, especially among the early Dutch prints that dominate the collection.

"We are trying to create a collection that has cohesion," says Meakins, who is now retired but pursuing a graduate degree in art history at Montréal's Concordia University.

And that is what the doctors have done with the Dutch Golden Age. The exhibition reveals the evolution of landscape prints in Flanders and The Netherlands from the Milites Requiescentes, after the design of Pieter 


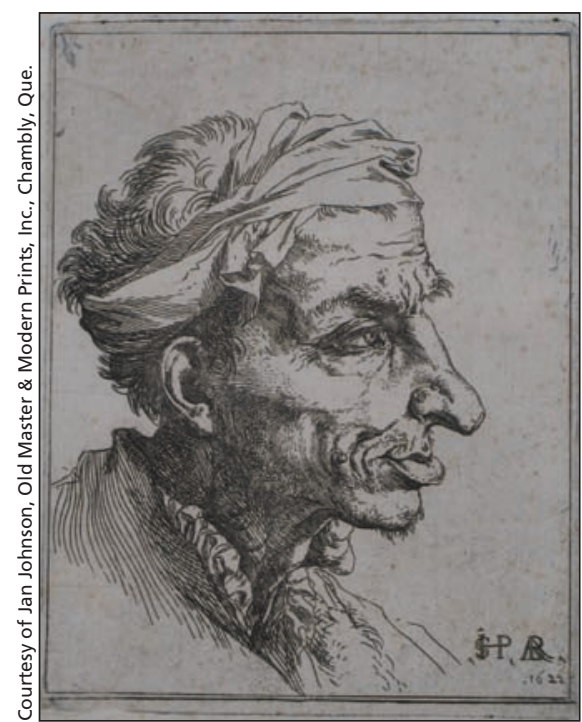

Jusepe de Ribera's The Small Grotesque Head (1622) depicts a man with signs of neurofibromatosis type 1 (formerly known as von Recklinghausen's disease). (This particular version of the print is not from the exhibit.)

Brueghel the Elder, executed in the 1550 s, to portrayals of everyday life through such genre scenes as Rembrandt's The Rat Catcher in 1632.

The majority of these black-andwhite works, which are displayed dramatically on cobalt blue walls, exude serenity as smiling peasants go about their daily business in quaint villages or pastoral settings. But some are filled with tension and even horror, as we witness scenes of tortured martyrs or, like Ribera's The Lamentation, 1591, people mourning Christ's dead, broken body.

That Ribera is one of four prints in the exhibition the doctors are donating to the museum to mark that institution's 150th anniversary. Two others are medically themed Ribera prints, which particularly delight the museum because, beforehand, it owned no prints by that artist. Ribera's The Small Grotesque Head and The Large Grotesque Head were both executed in 1622. Both prints show the heads of two physically repugnant men with warts and tumours on the neck, clear signs of neurofibromatosis type 1 (formerly known as von Recklinghausen's disease).

The show was curated by Meakins, with help from Goldfarb. Meakins took the lead in selecting the prints for exhibition and composing explanatory wall texts. Museums rarely permit non-

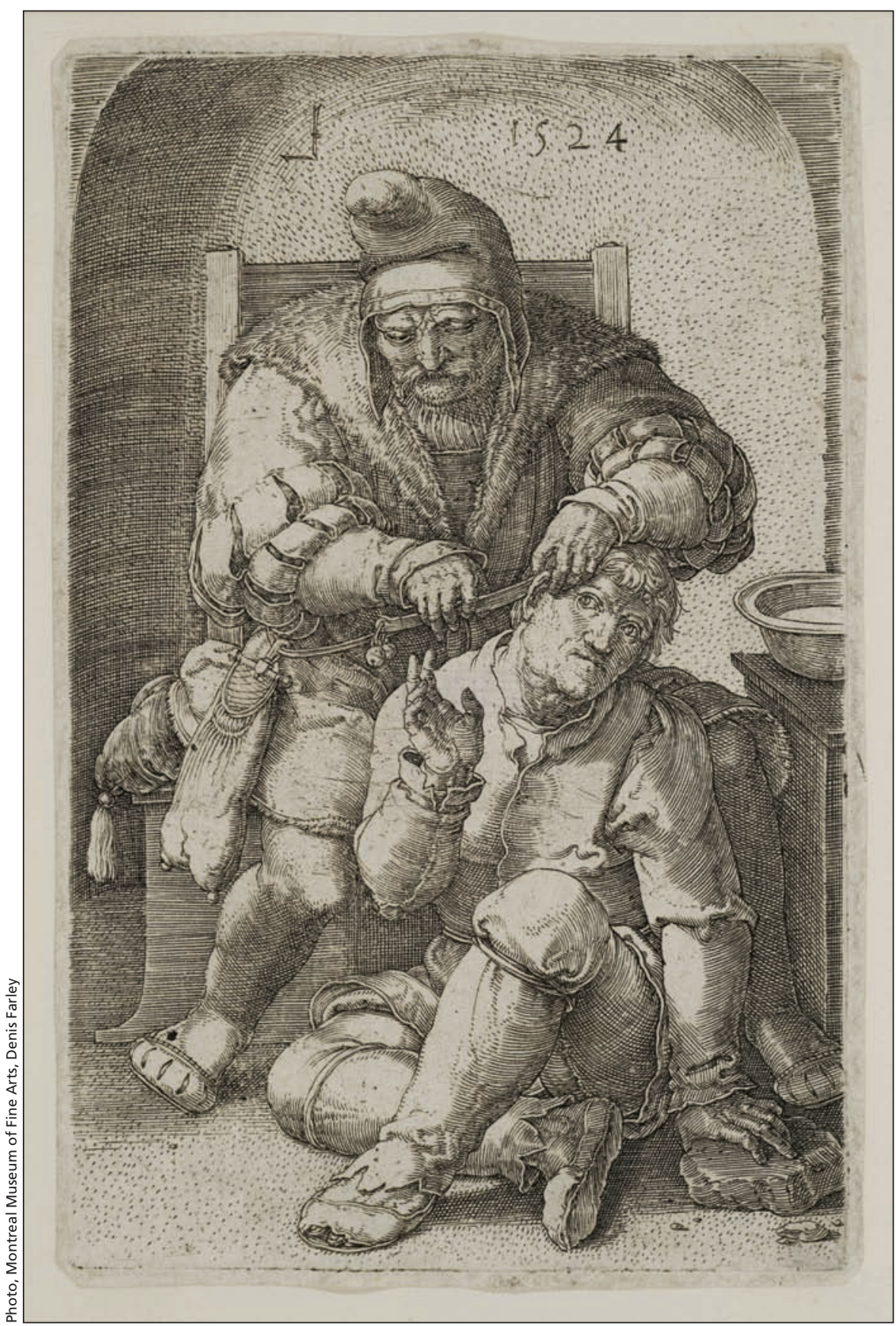

In Lucas Van Leyden's engraving The Surgeon (1524) a man's head is sliced open to cure him of stupidity. Collection of Dr. Jonathan Meakins and Dr. Jacqueline McClaran.

professionals to play such a role, even when the shows are of a particular collector's holdings. But Goldfarb, recognizing the passion and expertise of Meakins, gave him a relatively free hand and, he says, he is glad he did.

In an interview, Meakins said he and McClaran decided to become print collectors for two main reasons. First, they love the aesthetics of prints, believing the well-defined lines and the black and white contrast exude "power." Second, they love such Old Masters as Goya, Rembrandt and Durer but cannot afford to buy their paintings. Prints are the next best thing. The doctors spend years hunting for a particular print.

The result is a unique body of work reflective of the physician's eye.

\section{Paul Gessell BA}

Critic

Chelsea, Que.

CMAJ 2011. DOI:10.1503/cmaj.110787 